頸部リンパ節転移から発見され，再発をくりかえしている 微小甲状腺癌の 1 例

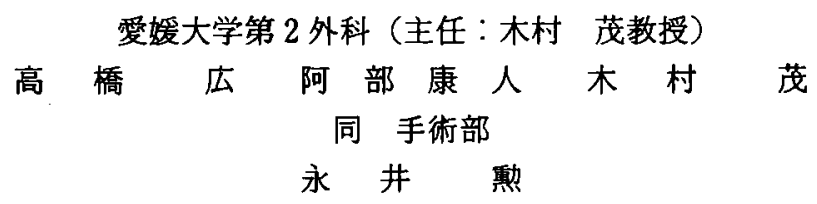

頸部巨大リンパ節転移から発見された不顕性甲状腺癌の 1 例を経験した，症例は61歳 男性. 左鎖骨上窝尾瘤を主訴に来院. 腫瘤摘出により甲状腺癌の頸部リンパ節転移之診 断された。 5 日後，甲状腺左葉切除，R1リンバ節郭清を施行した，その後, 頸部所属り ンバ節，頸部，前胸部皮下組織，上縦隔，胸骨，肺に再発転移をきたし，肺を除く再発 転移巣に対して計11回摘出術を施行した。現在, 初回手術後 7 年 6 カ月になり両肺転移 を認めるる担癌生存中である. 再発甲状腺癌に対する積極的な外科切除に加え, 初回治 療方針の重要性を強調した。

稒引用語：不頭性甲状腺癌, 再発甲状腺癌, 綎隔内再発

はじめに

甲状腺分化癌は他の悪性腫瘍と比べ, 発育が緩慢で 予後良好と言われており，20年生存率の報告む見られ る1”。しかし少数例ではあるが再発を繰り返し治療に 難涉する症例す見られる. 今回, 頸部巨大リンパ節転 移から発見され，再発を繰り返し，治療に難洗してい る㹵小甲状癌症例の治療上の問題点について検討を 加光報告する。

\section{应例 \\ 患者：61歳，男性.}

主訴：左鎖骨上简腫瘤。

家族歴，既往歴：特記すべきことなし．

現病歴：昭和56年12月左鎖骨上简の腫瘤に気つき当 科外来受診し, 悪性厦愓の Virchow 転移々診断され精 查治療目的にて入院した。

入院時現症：体格は中等度で，栄養状態は良好で あった，左鎖骨上简，胸鎖乳突筋後面に可動性不良， 表面不整，弾性硬な $7 \times 5 \times 4 \mathrm{~cm}$ の腫瘤を触知した。 甲 状腺には腫瘤を触知しなかった。

検査成紿：血液, 生化学検査, 甲状腺機能検查は正 常. 腫湯マーカーはサイログロプリンの上昇 (310ng/ $\mathrm{ml})$ 以外すべて正常. 甲状腺 ${ }^{99 m} \mathrm{Tc}$ シンチタララムでは

1989年 9 月 8 日受付 1990 年 2 月 14 日採用
甲状腺の陰影欠損はみられない，頸部軟線撮影にて気 管扁位，異常石灰化を認めない，胸部単純 X 線写真で は異常陰影を認めない。

臨床経過（図 1)：57年 1 月左鎖骨上蒚の腫瘤を摘出 し，甲状腺乳頭腺癌のリンパ節転移之診断された（図 2). 5 日後甲状腺左葉切除, R1 ソンハ節郭清を施行し た。原発巣は甲状腺左葉下極に発生した $9 \times 8 \mathrm{~mm}$ の non-encapsulated sclerosing carcinoma であった（図 3). 左の上内深頸, 下内深頸リンパ節に転移を認めた. 57 年12月正中顎下部の小指頭大転移リンバ節を摘出し た. 58 年 4 月両側頸部りンパ節を郭清し，左の上内深 頸，䪾下リンバ節に転移を認めた。 59年 1 月前頸部皮 下の転移リンパ節を摘出した。 59 年 4 月 CT 検查にて 左右鎖骨上窝から上縦隔に及ぶ腫瘤を認めた。 59 年 5 月胸骨稆切開, 嫩状切開により右側顠部リンバ節郭清, 両鎖骨上简リンパ節郭清, 前糈隔リンバ節郭清を施行 した，両鎖骨上窝リンバ節に転移を認めた。60年 1 月 左側頸部の転移りンハ節を摘出した，60年 3 月頃より 前頸部, 胸骨柄の腫瘤出現し， 7 月襟状切開，胸骨切 痕下方 $5 \mathrm{~cm}$ の皮启切開を加党，残存甲状腺右葉摘出， 前頚部皮下, 左鎖骨上下のリンパ節を摘出, 胸骨柄一体 上部合併切除, 左内頸静脈合併切除を施行した。 甲状 腺右葉の腺内播種, 右反回神経入口部の浸潤を認めた。 摘出したリンバ節全てと胸骨に転移を認めた，胸骨欠 

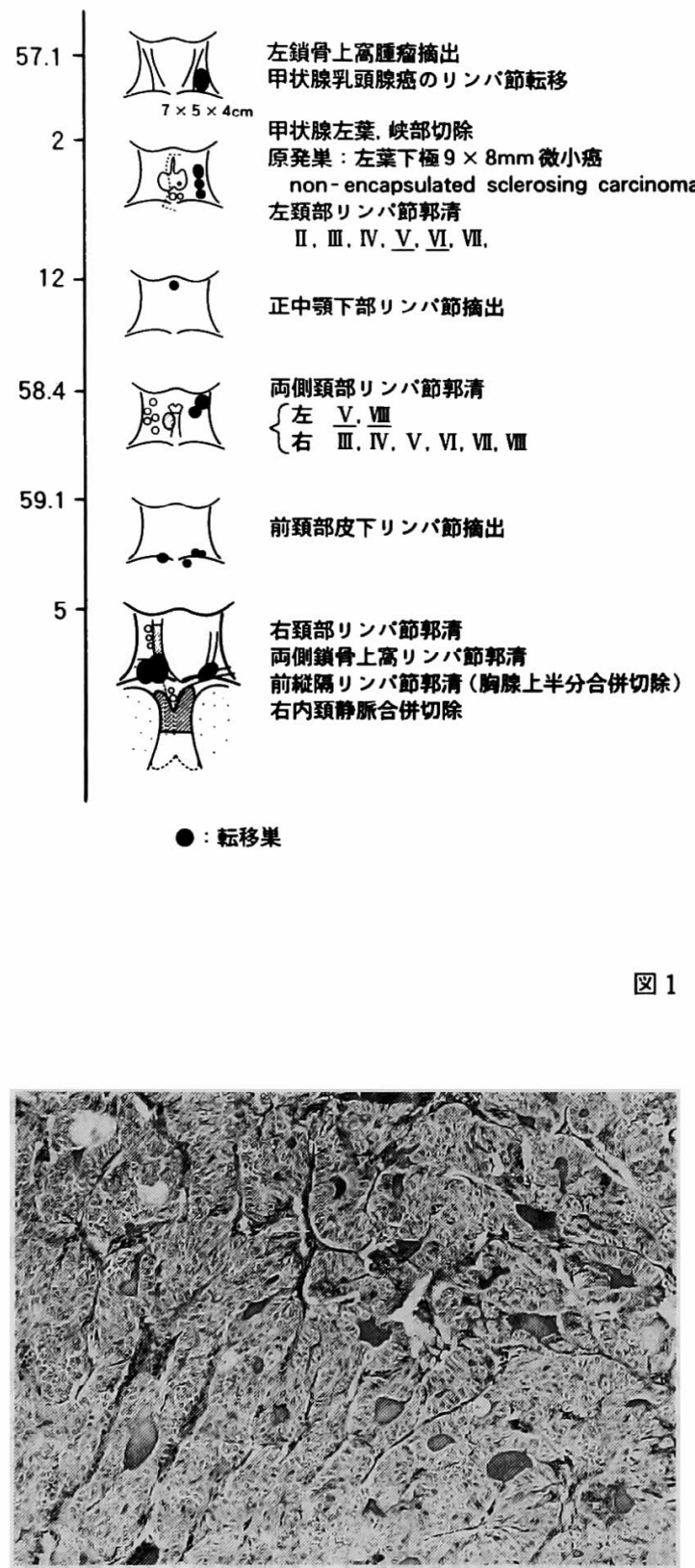

図 2 頸部転移リンパ節の組織像：乳頭状増殖が著明 な甲状腺癌で，腺腔構造を認める部分が多いが，部 分的に充実性，索状配列を示し，腺腔を作らない低 分化癌の部分も存在する。

損部はメタルメッシュ, 及び bone cement にて補媜し た. 術後, 両側反回神経麻㾝, リンパ漏, テタニーを おこし，2 日後気管切開を施行した。リンパ漏，テタ ニーは保存的治療にて軽快した。60年 9 月の胸部 CT

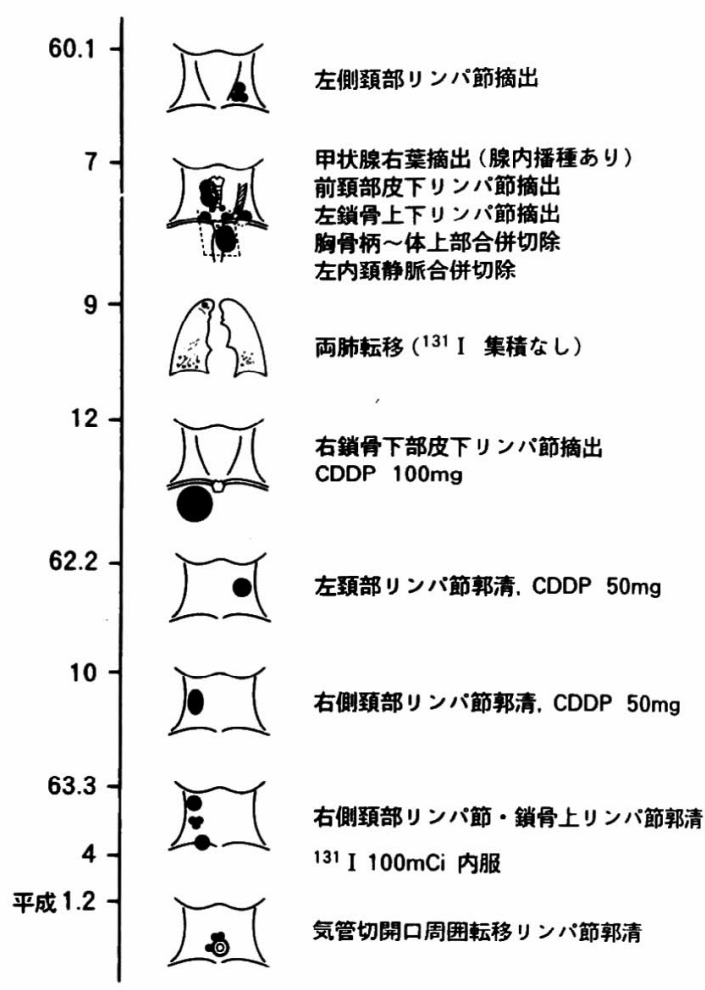

図 1 臨床経過

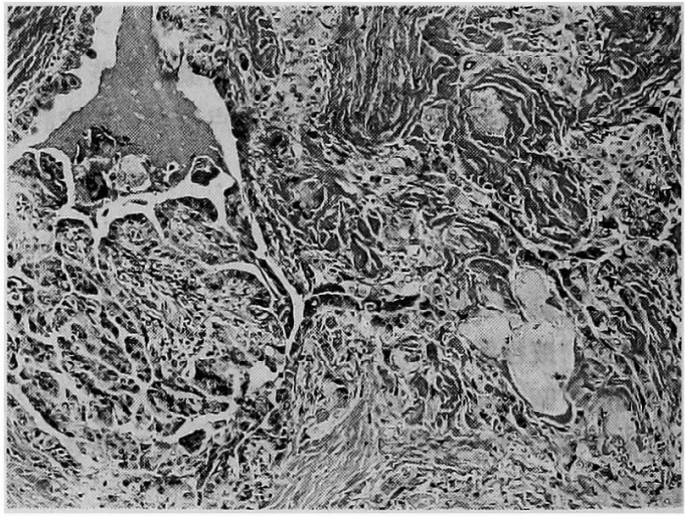

図 3 甲状腺原発巣の組織像：甲状腺乳頭腺癌巣内に 高度結合組織増生をともない, 周囲滤胞間に放射状 に浸潤性発育を示す。

で両肺に粟粒様の転移と思われる陰影を認めたが, 131 I の集積は認められなかった。 60 年 12 月右上前胸部皮 下の $8 \times 9 \mathrm{~cm}$ の転移腫瘤を摘出した。61年 5 月胸骨補 填部の感染のため補媜材料を除去した。 62 年 2 月, 10 
月，63年 4 月にそれぞれ左内深頸転移りンパ節郭清， 右側頸部転移リンバ節郭清, 右内深頸・鎖骨上転移り ンパ節郭清を施行した. 63 年 4 月 ${ }^{131} \mathrm{I} 100 \mathrm{mci}$ を投与し た。平成元年 2 月気管切開口周囲の皮下転移腫瘤を摘 出した. 初回術後 7 年 6 カ月経過した現在，両肺転移 を認めるす担癌生存中である。

\section{考 察}

微小甲状腺癌は1927年 $\mathrm{Graham}^{2}$ が甲状腺機能元進 症に合併した直径 $10 \mathrm{~mm}$ 以下の微小癌 6 例に対し "Adenocarcinoma not originating in adenoma" $z$ 記載したことに始まる。 その後微小甲状腺癌の定義に ついて諸家により議論されたが，1976年シカコで開催 された国際会議以来，リンパ節転移の有無にかかわら ず，腫湯最大径 $1 \mathrm{~cm}$ 以下の甲状腺癌とい5意見に統一 されつつある。

一般に牧小甲状癌の予後は径 $1 \mathrm{~cm}$ 以上の顕性癌 のそれに比して良好である゙。しかし遠隔転移を生じ た微小甲状腺癌症例報告されており とはいえ，予後不良例が存在する。高溦小甲状腺癌 の局所リンパ節転移率は $30 \%$ - $60 \%$, 甲状腺内播種は $40 \%$ 50\%認められると報告されている(4)5). 本症例の ごとく，頸部巨大リンパ節転移から発見され，再発を 繰り返し, 治療に難浩している㟫小甲癌症例は比 較的稀である，亀谷等6は頸部リンパ節転移から発見 される微小甲状腺癌（不顕性癌）の頻度は，甲状腺癌 231例中 4 例（1.7\%）と報告している。

頸部リンバ節転移が主症状で原発巣が微小な場合に は，原発巣を触知できず診断困難なことが多い，自験 例も甲状腺原発巣を触知できす，甲状腺癌以外の悪性 隀瘍からの Virchow 転移を考え, 腫瘤を摘出して初め て甲状腺癌の頸部りンパ節転移之診断された。当科で は，6年前より穿刺吸引細胞診を導入し約 $90 \%$ 正診 率を得ている7. 本症例に術前 aspiration cytology を 施行していれば容易に診断がつき，一期的に頸部リン 八節転移腫瘤を含め甲状腺切除を施行できたと思われ る.

再発を繰り返した原因として，1）初回手術時の甲状 腺切除及びリン・節郭清が不十分であった事，2）再発 時, 残存甲状腺の摘出時期の遅れを含め適切な広範囲 リンパ節郭清が行われていなかったこと、3）本症例が 40 歳以上の男性で組織学的に坂本等》の提唱している 低分化癌であり, high risk group の範中に入ることが 考えられる。野口等 ${ }^{5}$ は，徽小癌においても甲状腺実質 内転移の類度が予想以上に高く $(41 \%)$ ，リンパ節転移
から発見される不顕性癌には甲状腺亚全摘及び両側り ンパ節郭清を，また腺内転移が対側葉にあるものには 甲状腺全摘を行らべきであると述べている，また藤 本 ${ }^{91}$ は内深頸リンパ節転移のみが目立ち, 原発巣が触 知不能あるいは小さいときには浸潤増殖傾向が強い甲 状腺癌であると見なし，また同時に血行性転移を起こ していることが多いので，甲状腺全摘及びリンバ節郭 清を徹底的に行らべきだと述べている，自験例では初 回手術時すでに反対側（甲状腺右葉）に腺内転移を和 こしていたかどらかは不明であるが，下内深頸リンパ 節に一塊となった大きなりンハ節転移を認め, 初回手 術時甲状腺重全摘あるいは甲状腺全摘, 徹底した両側 リンパ節郭清を行らべきであったと考えられる。

鎖骨上窝から上維隔に及ぶリンパ節再発には胸骨繸 切開により良視野のもとで積極的に再発腯瘤を摘出

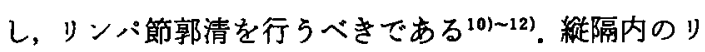
ンパ節郭清範囲に関しては概ね腕頭静脈のレベルをで でよいとされているが稀に腕頭静脈より尾側に転移が 認められることもある(2). 私達は今まで本症例を含め 3 例の甲状腺癌縱隔内再発症例に胸骨縦切開により腫 瘤摘出，気管分岐部までのリンパ節郭清を施行してき た. 3 例中本症例以外の 1 例に腕頭静脈より尾側に転 移が認められ，今後も気管分岐部までのリンバ節郭清 を clinical trial として行ら方針でいる. 現在, 患者は 槑隔内再発リンパ節を摘出後, 絽隔内には再発を認め ていない.

本症例の経験をもとに, 頸部リンパ節転移で発見さ れた䵇小甲状腺癌の治療方針を検討した。 まず頸部畽 瘤の Aspiration cytologyにより, 甲状腺癌のリンパ 節転移がどうか診断し，つぎにEcho，CTにより原発 巣及び腺内転移, 遠隔転移の有無を険索する。術前原 発巣及び腺内転移が不明な場合には，㭪中甲状腺全体 を触診, echo 等により充分検索し, すし腺内播種があ れば一期的に甲状腺全摘, 両側頸部のリンバ節郭清を 行5.腺内播腫がなければ甲状腺严全摘, 両側頸部リ ンパ節郭清を施行する. 術後, 血中サイログロブリン の測定, 全身スキャンを行い, 局所再発, 遠隔転移の 早期発見に努め，再発が見られた場合には系統的リン パ節郭清あるいは社I療法を施行したいと考えてい る.

再発を繰り返すごとに病着が強くなり，手術が困難 になり術中合併症の危険性が増えるため, 初回手術治 療方針がきわめて重要であると考古られた。 
おわりに

頸部巨大リンパ節転移から発見され，再発を綝り返 し治療に難沾している兴小甲状腺癌の治療上の問題点 を中心に考察を加兄報告した，再発転移巣に対する積 極的な外科切除に加光, 初回治療方針の重要性を強調 した。

稿を終えるにあたり，病理組織学的な考察をいただいた 受媛大学第 1 病理植田規史助教授に深勆致します。

\section{文 献}

1）宝道 勝：甲状腺癌の予後を左右する因子の追求 と治療法の選択, 日外会誌 $86: 32-43,1985$

2) Graham A: Malignant thyroid. Proc Interstate Postgrad M A North Am (1927) 3: 264, 1928

3) Patchefsky AS, Keller IB, Mansfield CM : Solitary vertebral column metastasis from occult sclerosing carcinoma of the thyroid gland. Am J Clin Pathol 53: 596-601, 1970

4）荍下和久, 野口昌邦，田中茂弘他：小甲状腺癌再 発再手術の 2 症例, 外科診療 27 ：1219-1223， 1985
5）野口昌邦，橋本哲夫，熊本健雄他：微小甲状腺癌と それ以外の甲状腺癌の臨床病理学的比較検討, 外 科診療 $25: 1168-1173,1983$

6) 亀谷 徹, 竹田千里, 海老原敏他：小型ならびに改 小甲状腺癌に関する臨床病理学的研究, 日臨 35 ： 2581-2588, 1977

7）東権 広：穿刺吸引細胞診による甲状腺腪掦の診 断, 日外会誌 $84: 612-622,1983$

8）坂本穆彦, 河西信勝, 北川知行他：再発率·死亡率 からみた甲状腺低分化癌の特改, 癌の臨 $32: 955$ $-957,1986$

9）藤本吉秀：転移を伴万甲状腺癌の治療方針，外科 $45: 246-251,1983$

10）三村 菅谷繁年，茂木克彦他：甲状腺進行癌 一綎隔転移例の郭清について一，内分泌外科 2 : 287-291, 1985

11）飯田太：甲状腺癌外科治療の現況, 日外会誌 $89: 1343-1346,1988$

12）水野 茂, 舟楿㤵臣, 杉浦勇人他：甲状腺乳頭癌に 対する広範囲リンバ節郭清術と転移リンバ節の検 討, 日外会誌 $87: 883-888,1986$

\title{
OCCULT THYROID CANCER PRESENTING AS GIANT CERVICAL LYMPH NODE METASTASIS
}

\author{
Hiroshi TAKAHASHI, Yasuhito ABE and Shigeru KIMURA \\ Second Department of Surgery, Ehime University School of Medicine \\ Isao NAGAI \\ Operating Center of Ehime University Hospital
}

This paper describes a case of occult thyroid cancer which was found from giant cervical lymph node metastasis.

A 61-year-old man was admitted to our hospital because of a left supraclavicular tumor in December 1981. He was diagnosed as having cervical lymph node metastasis of thyroid cancer after excision of the tumor. Five days after the removal, left lobectomy of the thyroid gland with ipsilateral modified neck dissection was performed. After surgery, recurrence occurred in the cervical lymph nodes bilaterally, as well as the subcutaneous tissue and the mediastinal lymph nodes. Also lung and sternal metastases developed. Recurrent tumors (except for the lung metastasis) were resected 11 times in a 7 year peroid. This patient is now alive 7 years after the initial operation, although lung metastasis is still present. The significance of the initial therapeutic approach to recurrent thyroid cancer is emphasized. 